\title{
DANIEL KISS \\ NEW NORMS - OLD MODUS. \\ TENSIONS FROM SOCIALIST PLANNING SURVIVING \\ THE REGIME CHANGE IN HUNGARY
}

Daniel Kiss, ${ }^{1} \mathrm{PhD}$, Lecturer at the Network City Landscape, ETH Zurich; HIL H 44.1, Stefano-Franscini-Platz 5, $\mathrm{CH}-8093$ Zürich.

E-mail: kiss@arch.ethz.ch

\section{Abstract}

Post-socialist transformation is a widespread phenomenon with numerous variations. Even if the study is restricted to Eastern European countries, their recent developments vary depending on their distinct socio-economic contexts and historic path dependencies.

In constructing new planning systems, these countries did not have a single model to follow. What they shared, however, is that the emerging market system demanded new regulatory forms of planning that were alien to the socialist planning tradition, in which the plan operated more as a horizontal structure synthesizing a range of sectoral public investment programs [Tsenkova, 2011]. Whereas the phenomena of post-socialist urbanization are elaborately reviewed and debated in the discourses on urban geography, economy and governance, the literature on urban planning in these cities is very limited. The first generation of studies on the era's planning challenges, lacking sufficient empirical material, offered generalized accounts of the links between land reforms, the alienation of real estate, and the development of planning institutions [Andrusz, Harloe, Szelényi, 1996; Bertaud, Renaud, 1997; Hamilton, Andrews, Pichler-Milanović, 2005; Tsenkova, Nedovic-Budic, 2006; Stanilov, 2007]. In response, this paper presents an empirically deep single case study of the urban planning regime's transformation in Budapest between 1990 and 2010. It introduces the substantial time shifts between the reforms in different domains and the resulting tensions. Whereas economic reforms had already targeted the decentralization of the planning under socialism in the 1960s, the spatial planning system's persistence remained apparent even in the years following the regime change. With the rapid and excessive post-socialist decentralization of authority, political competences concerning urban planning were delegated to lower levels. In contrast, its modus operandi long remained largely unchanged, not properly adapted to the transformation of the economic and political systems. The hypothesis is that there exists a nexus between the persistence of socialist planning and the laissez-faire type of post-socialist urban development by means of the internal tensions within the urban planning system and its resulting dysfunctionality under the new market conditions.

The methodology for this study draws on content analysis of policy documents and secondary sources of analytical information pertinent to the urban planning regime in Budapest during the time period under investigation, supplemented by personal interviews with major stakeholders.

Key words: post-socialist; spatial planning system; development; Budapest; privatization; planning documentation Citation: Kiss D. (2018) New Norms - Old Modus. Tensions from Socialist Planning Surviving the Regime Change in Hungary. Urban Studies and Practices, vol. 3, no 4, pp. 18-34.

DOI: https://doi.org/10.17323/usp34201818-34

1 Dr. Daniel Kiss (b. 1978, Budapest) is lecturer at the Network City Landscape, ETH Zurich. His field of expertise comprises theories of urban form, strategic design, as well as post-socialist urbanization. His work has been supported by multiple grants from the Swiss National Science Foundation (SNF). Besides his research activities, he teaches urban design studios and theory seminars, lectures on strategic design, and moderates the NSL Institute's doctoral colloquia. He holds a PhD from ETH Zurich and an M.Arch. from Harvard University. Daniel previously worked as project architect with Herzog \& de Meuron and is founding partner of the Baselbased architecture and urban design practice XM Architekten. 


\section{Market Socialism and Planning Reforms}

$\mathrm{T}$ The roots of this narrative are to be found way back in the 1960s. The economist János Kornai coined the term 'premature welfare state' to characterize those socialist states, among them Hungary, which introduced generous welfare services, for example in the form of public housing and health-care systems, while the state of their economies did not allow for the allocation of sufficient resources for these measures [Blanchard, 1999].

In response to the resulting tension, the Hungarian party-state cautiously installed economic reforms in 1968, aiming at a partial marketization of its welfare systems. The 'New Economic Mechanism' was an all-around restructuring of the planning and commanding of the socialist economy, redusing the role of central planning, increasing corporate autonomy and installing a limited price competition. ${ }^{2}$ Kornai claims that the paternalistic state's provisions were supposed to maintain or regain support for the regime and had mixed results, especially following the economic reforms. On the macroeconomic level, the welfare reforms caused high inflation, budget deficits and growing over-demand for loans, an unfavorable trade balance and surging debt and, as such, had a negative impact. However, they had positive consequences on the micro level: real property, well-functioning legal infrastructure, a management elite and a working class whose members knew more about how the market economy works - all this contributed to making reformist states more attractive for foreign investment.

With this shift towards 'market socialism,' the decentralization of the production of space also took its first steps. Firstly, private property made its appearance in the housing sector. A 1969 Government Decree awarded the right of designating properties for alienation to the territorially competent councils and the construction of private apartments and single-family houses was also made possible. ${ }^{3}$ Approximately 100,000 such dwelling units were erected in Budapest between 1961 and 1980, almost twice the target number of 54,000.4 Secondly, despite the establishment of some sort of a price competition, socialist enterprises were involved in 'competition without a real market,' as the Polish geographer Bohdan Jałowiecki pointed out. Instead, these firms started challenging each other in the accumulation of all kinds of resources, among other things, space [Jałowiecki, 1988]. ${ }^{5}$ This resulted in central urban areas becoming dotted with a hodge-podge of real estates in the possession of industrial firms. A further consequence of this hoarding of space was a shortage of space despite the not particularly dense land use of the socialist city. ${ }^{6}$ The decentralization of spatial planning itself culminated in 1986 in a Decree of the Council of Ministers, which delegated the enactment of General Urban Plans (GUP) from the central government to the city councils. ${ }^{7}$

\section{The Socialist Planning System vis-à-vis Decentralized Authority and Land Reforms}

Despite the partial reforms, under the party-state system all collective decisions, whether political or economic, were taken within a single, unified hierarchy. After the regime change of 1989, centralizing tendencies gave way to trends of decentralization, resulting in the accelerated fragmentation of the political and economic systems. Amongst other domains, the changes were highly conspicuous within local governance, as here the appeal to democracy and self-rule gave a strong ideological push to the decentralizing drives. A two-tier municipal system with a uniquely powerful

2 The so-called 'New Economic Mechanism' was elaborated in the mid-1960s and enacted on January 1, 1968. It contained the following major changes: 1 ) it reduced the role of central planning and increased corporate autonomy in production and investment; 2) it liberalized prices, allowing the price of certain products to be set in accordance with market demand; and 3) it replaced the centrally determined wage system by a flexible regime, in which companies could determine wages, albeit within certain limitations [Rainer, 2010].

3 Government Decree 32/1969 (September 30).

4 19,504 between 1961 and 1965, 22,507 between 1966 and 1970, 28,922 between 1971 and 1976, and 27,654 between 1976 and 1980 [Kondor, Szabó, 2007].

5 Jałowiecki argues that by maximizing the assets made available to them, including space, socialist enterprises could secure political influence and constant growth.

6 Influenced by Kornai's seminal theses on what he called the economy of shortage and soft budget constraints, the anthropologist Katherine Verdery introduced the constraints of production, mainly the shortage of supply as the socialist system's main structural problem. According to her, consequence was the padding of budgets and hoarding of materials, which resulted in widespread shortages [Verdery, 1996].

7 Regulation of the Council of Ministers 1027/1986 (May 22). 


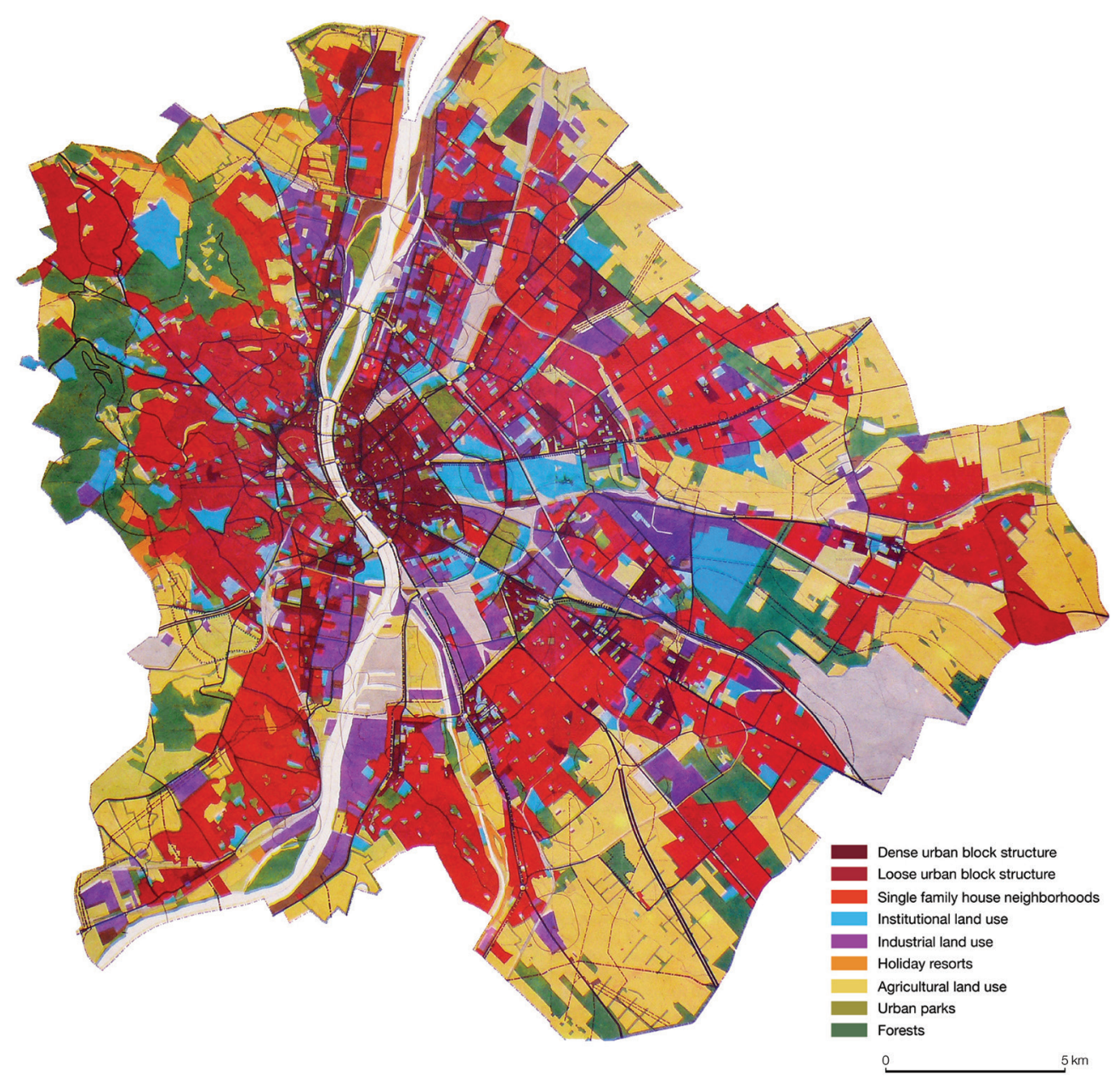

Fig. 1. Land-use and settlement structure plan of Budapest's 1988 General Urban Plan

Source: Budapesti Városépítési és Tervező Intézet (BUVÁTI), 1986.

and autonomous district level was introduced in Budapest in $1991 .^{8}$ This resulted in lack of clarity on the division of authority and competence between the city and the districts and in the laming of metropolitan level governance.

By contrast, in the first eight years following the political change, spatial planning laws and regulations inherited from socialism remained de facto in force, amongst them the Building Law from $1964^{9}$ and a General Urban Plan from $1988 .{ }^{10}$ While authority was decentralized and the conflicts of interest between different levels of public administration became more open, the planning apparatus inherited from socialism still operated within a unified hierarchy and over long time-scales.

The 1988 GUP (Fig. 1) remained in force between 1989 and 1998. Although it was adjusted from time to time, its structure and major content remained unchanged. It foresaw a population decrease of 80,000 over the following 15 years, and anticipated - in accordance with the $7^{\text {th }}$ Five Year Plan the construction of about 10,000 new dwellings by 1995 (Fig. 2). 6,000 of these were supposed to be built in mass housing neighborhoods, while the building of another 4,000 was foreseen as densi-

8 Act XXIV/1991 (June 12)

The new law endowed Budapest's districts with the rights of individual townships, complicating the formerly hierarchical relationship between the city and its districts.

See more on the Hungarian decentralization of local governance in Modeling Post-Socialist Urbanization. The Case of Budapest [Kiss, 2018].

9 Act III/1964 (December 2).

10 Enacted with Decree 77/1989 (June 20) of Budapest's City Council. 


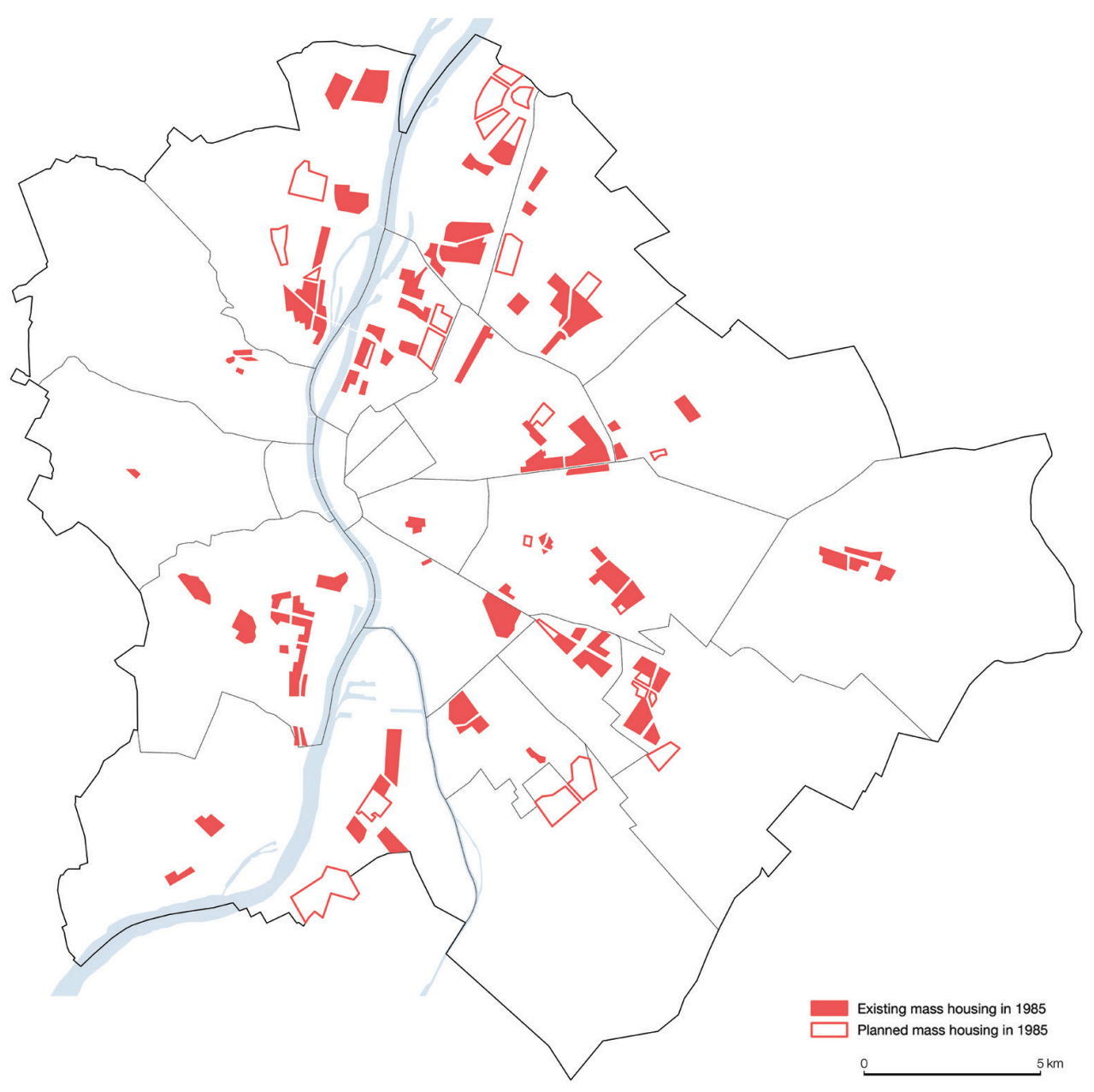

Fig. 2. Existing and planned mass housing estates in Budapest in 1985

Source: Illustration by the author, 2012. Original map: Budapesti Városépítési és Tervező Intézet (BUVÁTI), 1985.

fication projects within downtown renewal areas. In terms of infrastructure, the expansion of the metro network, and the construction of a highway ring around the city and of two new bridges over the Danube - both in the south - were focal elements of the plan. Furthermore, the GUP foresaw infrastructural improvements for the industrial areas already in existence, rather than providing for a further expansion of the territories for industrial land-use. Its two main promises remained unrealized: neither was the fourth (northeast-southwest) metro line built, nor was the state's mass housing program continued. The city's renewal programs were also lagging, leaving most of Budapest's neighborhoods in its second urban ring in degraded condition.

Not only were the authorities prevented by the collapse of the socialist economy from fulfilling the goals set by the GUP, the context of urban development had also dramatically changed by the transition to liberal democracy and a market economy. Resources and decision-making competences were decentralized, a real estate market based on a system of land value was reinstalled, and the accumulation of capital in private hands took place. In the 1990s Budapest's local governments privatized approximately $85 \%$ of the dwellings in their ownership [Dániel, 1996]. ${ }^{11}$ Besides the political aim of offering residents property rights, expressed by the 1993 Law on Housing, local governments

11 The state transferred ownership of public housing to the local municipalities, in the case of Budapest to the districts, soon after the regime change with Act XXXIII/1991 (August 2). The Act LXXVIII/1993 (July 30) on Housing, then, regulated the conditions under which the municipalities could alienate real estate to tenants. See more on the post-socialist privatization of housing in Budapest in Modeling Post-Socialist Urbanization. The Case of Budapest [Kiss, 2018]. 


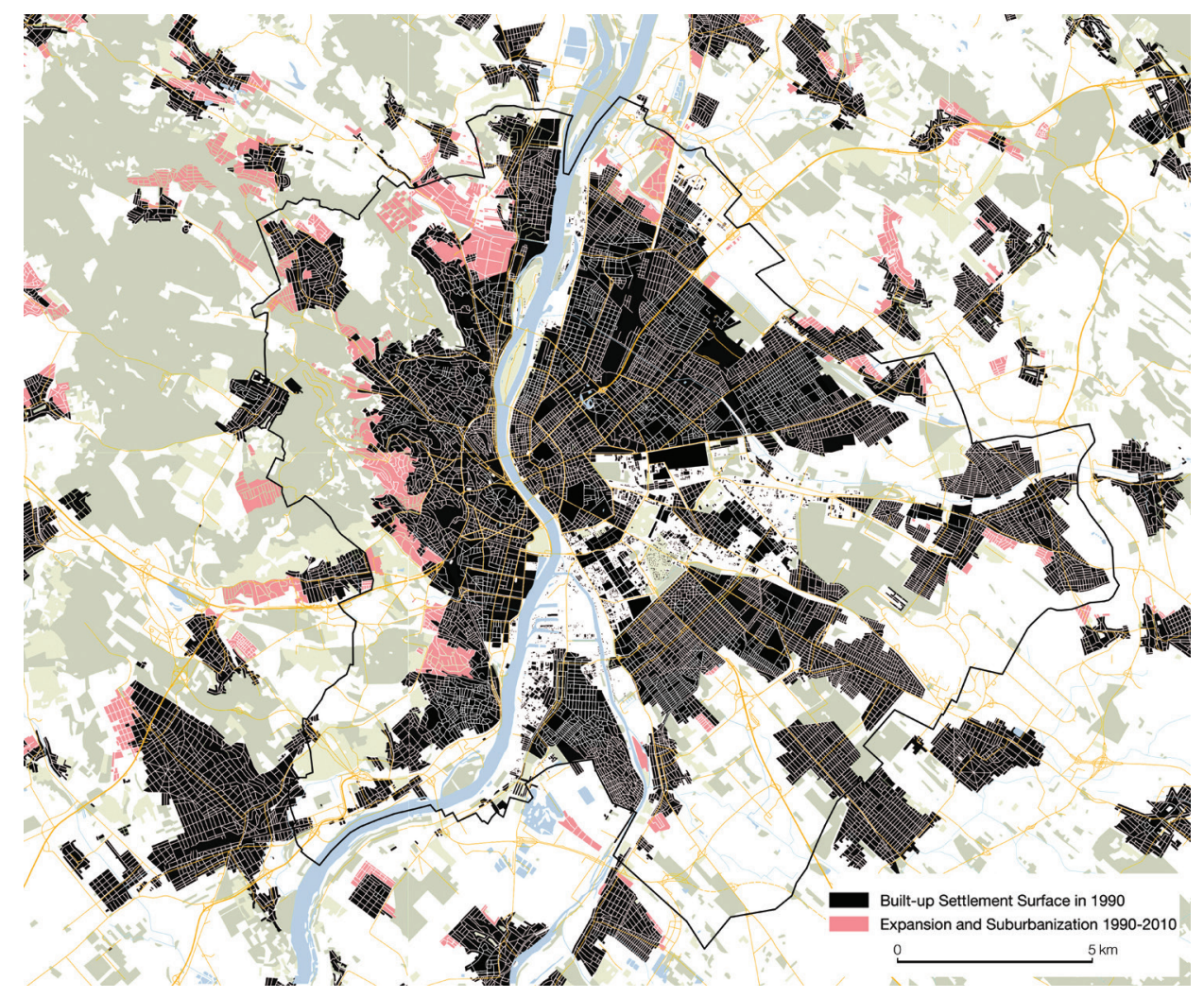

Fig. 3. Settlement expansion and suburbanization in Budapest between 1990 and 2010

Source: Illustration by the author, 2013. Base map: segments L-34-14 and L-34-15, Hungarian State Topography Map 1:25000, 1987; segments L-34-14 and L-34-15, Hungarian State Topography Map 1:50000, 2010.

were also motivated to alienate their housing stock for economic reasons. They hoped to decrease maintenance and renovation costs through the minimization of their real estate portfolios, while generating income through alienation for financing their tasks concerning the assets they continued to possess. Furthermore, they aimed to decrease their social responsibilities by substantially cutting back housing subsidies. This 'overnight' privatization of housing to former tenants induced a migration process, leading to enhanced spatial segregation [Ladányi, 2007], massive suburbanization (Fig. 3), ${ }^{12}$ and hung refurbishment and social housing projects.

Besides this decentralization of ownership, the replacement of the centrally planned economy by a market-based economic system also made it much more difficult to plan where developments within the city were going to take place, as these were mostly driven by market demand rather than state supply. Consequently, the developments foreseen by the 1988 GUP failed to come about while non-planned developments took off at an accelerated pace in areas outside of the scope of the plan; for example by former industrial facilities finding new functions in central urban areas. These developments outpaced the operations of planning. Radical transformations ran ahead of the respective amendments to the GUP, turning the plan itself retroactive and, thus, dysfunctional. As a result, the planning of land use and urban structure became a burdensome task, giving way to a rather laissez-faire type of urban development in the years following the regime change.

I will call this dysfunctionality of the planning apparatus amid the radically changed circumstances the first tension of urban planning in post-socialist Hungary.

12 A process in which Budapest lost around $15 \%$ of its population between 1990 and 2000 [Csanádi et al., 2010]. Budapest's population decreased from 2,016,774 in 1990 to 1,775,203 in 2001, while its agglomeration grew from 566,861 to 672,087 inhabitants over the same period. Data source: Központi Statisztikai Hivatal (KSH), census of 1990 and 2001. 
This period is often characterized as an era of 'wild capitalism,' meaning that the original accumulation of private property and the rise of the market economy were proceeding spontaneously, without proper regulation either as to who could access economic assets under privatization (and how); or whether vulnerable social groups enjoyed sufficient protection against the adverse effects of the economic transformation. ${ }^{13}$ The lack of adequate regulation also left its mark on the built environment. Investment by foreign and multinational firms was going on at an increasing pace [Némedi-Varga, 1998]. ${ }^{14}$ Some invested directly in real estate, while others got involved via land and real estate owned by the companies they purchased during the first large privatization wave in the production and service sectors. Not only was the regime of urban planning unable to fulfill its duty under these rapidly changing circumstances, but loopholes characterized the legal regulations in other domains as well.

This coincided with the city's urban planning department suffering serious cutbacks, due mainly to the insufficiency of financial resources. Prior to the regime change, the Budapest Institute of Urban Planning and Research (abbreviated as BUVÁTI in Hungarian) had been a huge state-held institution with 600-700 employees, working directly for the state and local councils. Under market conditions, BUVÁTI became unsustainable and was finally liquidated in 1997. The same year, Budapest's city municipality founded the Budapest Urban Development Planning Ltd. (abbreviated as BFVT in Hungarian), a firm employing 40-50 persons. ${ }^{15}$ The city continues to own BFVT and to commission it with the most important urban planning projects; for example, the preparation of revisions to the Settlement Structure Plan. However, planning tasks are increasingly being outsourced to private firms, especially by the districts which, in cases where they want to entrust their planning tasks to BFVT, are required to pay market fees. The replacement of BUVÁTI with a much smaller unit weakened the city government, leaving it with an unreasonably small planning department.

The belt-tightening of the planning regime took place during decisive years. The large-scale state projects shaping the growth of the socialist city were replaced in this period by innumerable lowlevel space appropriations, incremental in their dimensions and difficult to control, particularly in a climate dominated by the social imperative for deregulation and market liberalization. The weaknesses in the regulation had cumulative effects. For example, the lack of proper normative regulation on taxing added value for land and real estate was a notable factor distorting the impact on the city's

13 The sociologist Iván Tosics calls this period that of unfettered market, as opposed to the regulated market that was to follow [Tosics, 2013].

14 Western investment already made its appearance in the 1980s, after Hungary joined the International Monetary Fund in 1982. Throughout the 1990s, Hungary was a regional leader in terms of foreign capital investment. In 1996, it received 3,200 billion US Dollars, more than three times as much as in 1987, when 1,000 billion flew in.

15 BFVT had 44 employees at the end of 2014. See its public interest report from 2014, accessed April 13, 2017 <http://www.bfvt.hu/download.php?98bdd9a700fd3fdaeaead249522f88dd>. 
dealings with private developers and detrimental to their transparency. ${ }^{16}$ In many cases, development areas were sold first and their zoning categorization was only changed afterwards. In such cases, land was actually being sold way below its potential market value.

This dissonance between the pace of private investment, welcomed by resource-poor municipalities, and that of planning for these developments is the second important tension of post-socialist planning.

To make things even more difficult, as the planner and theorist Kiril Stanilov points out, the 1990s saw the influx into the urban planning arena of a number of new players who challenged the prerogatives previously enjoyed by planners in matters related to the distribution of space [Stanilov, 2007]. While some competences concerning spatial planning had already been delegated to lower levels in the last years of socialism, strategic planning remained concentrated at the highest echelons of political power, and planners were still called upon to determine how the defined goals would be incorporated into urban spaces. With the broad post-socialist delegation of decision making on matters regarding urban development to local authorities, the old-style symbiosis of political and professional decision-making was interrupted.

Not only did planners have a hard time in accepting that in a representative democracy the last word is with the elected bodies as a matter of principle, local politicians also began to see urban planning as a cumbersome process limiting their ability to respond flexibly to the 'opportunities of the moment.' Let's call this the third notable tension of urban planning in post-socialist Hungary.

\section{Controversies of Redistributive Renewal Policies}

As in other socialist cities, where housing was concentrated in mass housing satellites, the pre-war and inter-war blocks in Budapest's second urban belt had been neglegted until 1989. Thus, their renewal constituted one of the post-socialist period's most important development tasks. Along with the paramount decentralization of decision-making competences, the task of urban renewal in Budapest was delegated to the districts. At the same time, a metropolitan redistributive regime for the partial financing of renewal programs was introduced, based on revenues from the privatization of housing. ${ }^{17}$ This resulted in distortions in Budapest's urban development as the metropolitan administration ended up directing its financial resources away from the renewal tasks which it had prioritized. Its redistributive regime benefited districts with more advanced renewal programs or larger financial resources, further enhancing the prosperity gap between its poorer and better off neighborhoods (Fig. 4 and 5).

In 1994, the city government of Budapest regulated in a decree ${ }^{18}$ the conditions under which districts could apply for partial funding for their renewal programs from this fund. Until 1997 this opportunity was not made available to district municipalities other than those having contributed to the Renewal Fund. Furthermore, only apartment blocks with full municipal ownership were eligible for financial support, leaving municipal apartments within blocks of mixed ownership by the wayside. The Renewal Order of $1997^{19}$ extended the eligibility to privately owned condominiums. Furthermore, the city government committed itself to complementing the districts' deposits by almost doubling the Urban Renewal Fund's assets from other sources..$^{20}$ The third important amendment was the introduction of interest-free credits complementary to the non-refundable subsidies. To differentiating financial support, the Renewal Order borrowed the effective Urban Renewal Program’s territorial categories and

16 As István Schneller - chief architect of Budapest at the time - recalls in an interview with the author on March 29, 2011.

Neither did proper state-level legal regulation of taxing added value for land and real estate exist, nor did the municipality govern this issue by means of local orders.

17 The 1993 Law on Housing, besides regulating the conditions under which public housing was allowed to be privatized, resolved that Budapest's districts had to deposit $50 \%$ of their net revenues from the privatization of apartments into a central fund, called the Budapest Urban Rehabilitation Fund. This was to become the basis of a redistributive regime to at spread a substantial portion of the privatization income amongst districts. 18 Decree 33/1994 (June 10) of Budapest's General Assembly.

19 Decree 46/1997 (August 13) of Budapest's General Assembly.

20 The Urban Rehabilitation Resources of Budapest supported renewal projects with 5.4 billion Forints between 1997 and 2004, of which 4.1 billion were spent on refurbishing municipally-owned residential buildings, with another 1.3 billion on the subsidized development of complex infrastructural and public space projects. A further 4.6 billion was given out for the renewal of privately owned apartment blocks. 


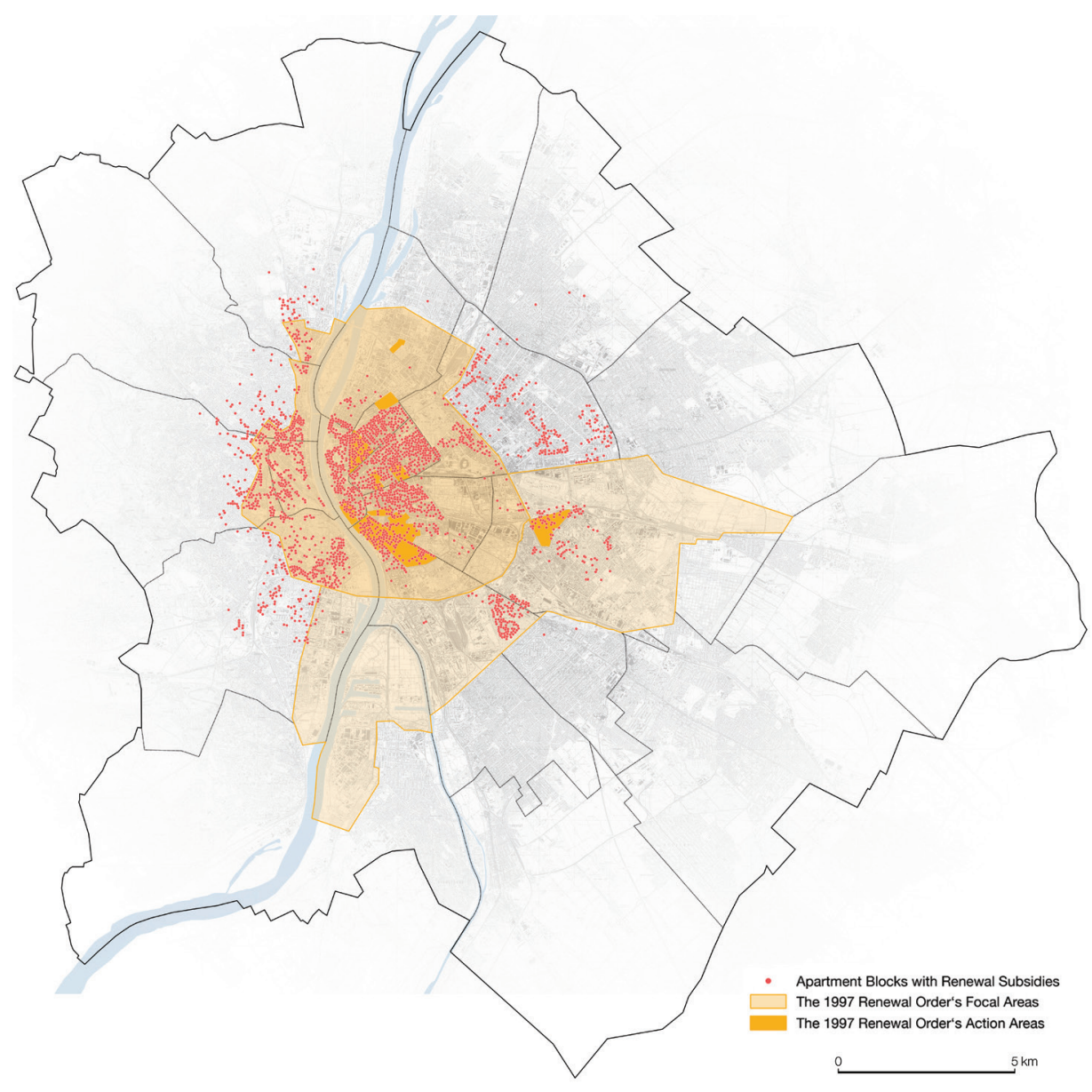

Fig. 6. Renewal subsidies of apartment blocks obtained between 1997 and 2004, superimposed on the focal and action areas of the 1997 Renewal Order

Source: Redrawn by the author, 2018. Budapest Városrehabilitációs Programjának felülvizsgálata és javaslat a program továbbfejlesztésére (Budapest: ECORYS Hungary Consulting, 2006).

gave priority to the so called 'focal areas' and 'action areas' (Fig. 6). By 'focal areas,' the Renewal Order roughly meant areas in the urban core and the second belt with urban blocks from the period of promoterism (marked in bright yellow on the map); whereas by 'action areas' it referred to smaller hubs designated by the city government within the focal areas for fast development (marked in darker yellow). Programs within these action areas were prioritized and no privately-owned blocks outside to the focal areas were eligible for financial support.

A study from 2001, commissioned by the city government to evaluate the practice of renewal subsidies, sums up two common criticisms of this regime [A Fóvárosi Városrehabilitációs..., 2001]. It insists first that no distinction was made among buildings on the basis of their owners' neediness - be they municipalities or private individuals. This resulted in the distortion of renewal subsidies, as these ended up being concentrated into better-off areas of the city. This distortion was further amplified by the fact that wealthier district municipalities were in a much better position to financially support housing renewal within their territories. Secondly, the city level subsidies were provided with no regard to other, ongoing support programs. This resulted, for example, in the supporting of block renewals that the respective districts refused to subsidize. Thus, the order was inconsistent with the Renewal Program which saw the role of city-level government mostly as strengthening and consolidating the district-level programs rather than introducing a new, independent layer of subsidies. One could add that the whole redistributive system of renewal funds was lacking any general strategy concerning the timing of the supported rehabilitation projects. Consequently, districts with already established 


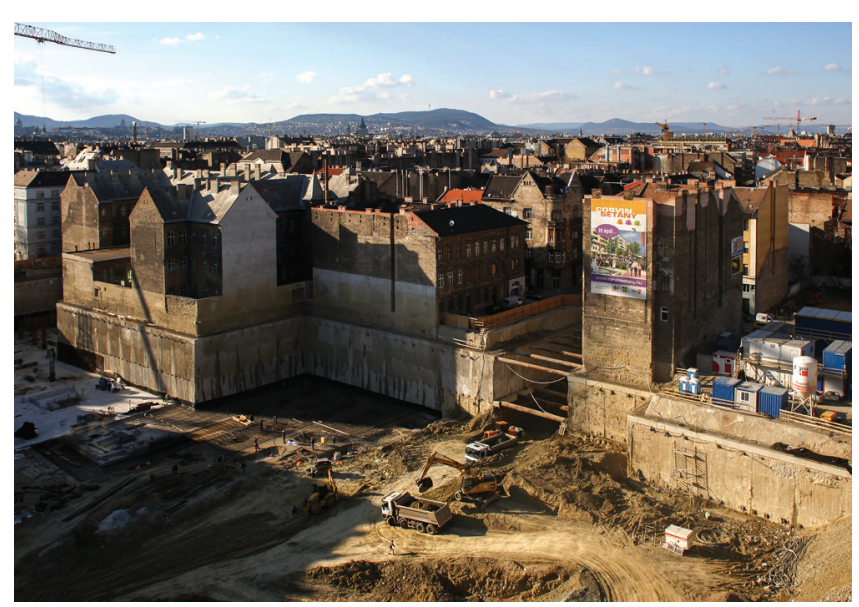

Photo @ Zsolt Reviczky, 2009

Fig. 7. Tabula rasa in the Corvin-Quarter in 2005

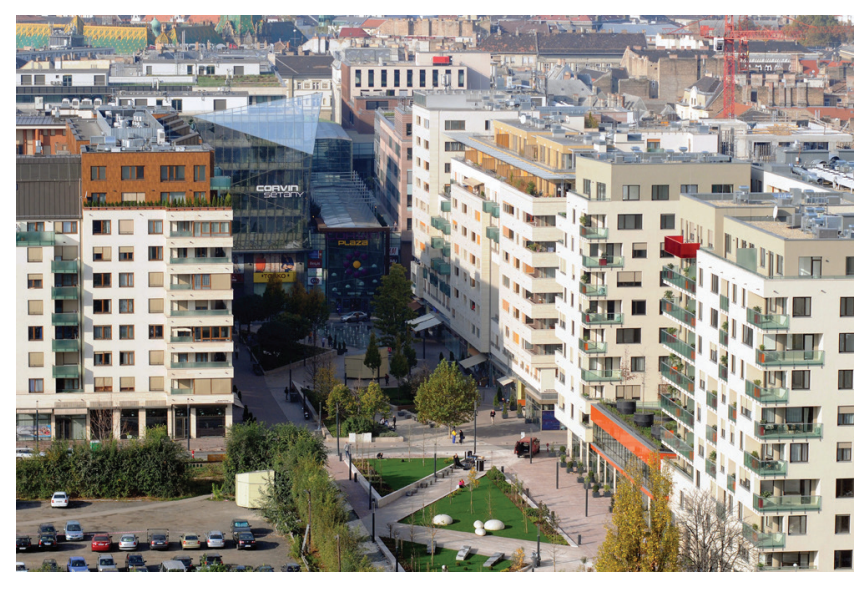

Fig. 8. Corporate architecture in the Corvin-Quarter
Photo @ Barnabás Honéczy / MTI News Agency, 2014

renewal strategies, or even ongoing programs, became the real beneficiaries of redistribution. By the time others caught up, a substantial portion of available funds had already been utilized. The biggest beneficiary was the $9^{\text {th }}$ district, which had had a block-scale rehabilitation program in effect since the mid-1980s. SEM IX. Co, an actor based on the French model Société d'Économie Mixte and independent of the local government, managed the privatization of real estate and the renewal of the district's inner areas'. Until 2001, approximately $50 \%$ of all funds were awarded to the $9^{\text {th }}$ district alone. Even more strikingly, between 1997 and 2001 the $9^{\text {th }}$ district collected 672 million forints for its complex renewal programs, which amounted to $71 \%$ of all available funds for the dedicated action areas of Budapest for this time [Somogyi, Szemzö, Tosics, 2007]. All in all, this district received a sum four times as large as what it had deposited into Budapest's Urban Renewal Fund after the successful privatization of its building stock.

In the 1990s, the neighboring $8^{\text {th }}$ district was neither comparably successful in applying for renewal funds at the city-level, nor could it attract private investors for the renewal of its housing stock. The reputation of the neighborhoods in this district was so bad that developers were afraid that their potential investment would soon be devalued. György Alföldi, former head of the district's Renewal and Development Company, claims that the $8^{\text {th }}$ district's lack of success was not an unforeseen outcome of impersonal processes and cannot be solely attributed to the controversies over the urban renewal regime. According to him, Budapest's political leadership wanted to cement the role of Józsefváros as the city's poor district and, consequently, was not willing to support their efforts with sufficient funds. In support of this claim, Alföldi argues that far less financial means were offered to Józsefváros from Budapest's central budget than what the wealthier $9^{\text {th }}$ district had received in previous years - whereas, according to him, larger subvention would have been the reasonable strategy. ${ }^{21}$ By contrast, Gábor Demszky, then mayor of Budapest, argues that the districts' overwhelming autonomy in the dual-tier system made the aspiration to have a coherent metropolitan-level strategy and planning utopistic [Demszky, 2012]. The frustration caused by the lack of development meant actors of the $8^{\text {th }}$ district's local municipality came to the conclusion by the mid-1990s that the block and building-scale renewal scheme of the 1980s, focused on refurbishing and conserving the existing stock, needed to be abandoned and radically different models developed instead. This led to the introduction of the investor project called Corvin-Quarter, Budapest's largest tabula rasa development since the regime change (Fig. 7 and 8). ${ }^{22}$

This discrepancy between the planning and budgeting of renewal programs post-socialist urban planning is the fourth tension.

The case of Budapest's $8^{\text {th }}$ district, in deciding in 1995 to replace its renewal developments with a tabula rasa investor project demonstrates the close interaction between the post-socialist reforms meant to restore local self-governance, the character of Budapest's redistributive renewal policies, and the difficult position in which some of the most disadvantaged districts had found themselves by

21 György Alföldi, in an interview with the author, September 27, 2014.

22 See more on the Corvin-Quarter development and its controversies in Modeling Post-Socialist Urbanization. The Case of Budapest [Kiss, 2018]. 
the mid-1990s; the rationalization of planning becoming ever more urgent.

\section{Retroactive Planning and the Absence of Projects of Symbolic Significance}

Although preparations for a new GUP commenced shortly after the regime change, it took almost a decade for the plan and the new regulations to be formulated. In this period, urban development was more agile than the GUP's planning, making the new plan by the time of its inauguration outdated. Furthermore, the publication of the new GUP on January 16, 1997 was a couple of months earlier than the enactment of a new Building Law which determined the means of spatial planning and building regulation. ${ }^{23}$ This sequencing proved to be fatal since the Building Law adjusted the modus operandi of settlement planning, replacing the GUP with the Settlement Structure Plan (SSP) and delegating some of the tasks of the former GUPs to the district-level Structure Plans. More precisely, the new law defined the SSP as 'a plan ensuring the achievement of the settlement development's objectives, and arranging the settlement's structure, its dominant land use, and the layout of its technical infrastructure networks. ${ }^{24}$ It resolved that District Structure Plans (the equivalent of the former Detailed Development Plans) were to be prepared by the districts of the capital. This was a major change with respect to the 1964 Building Law which allocated the task of giving guidance to the planned development of towns and cities to GUPs and resolved that, according to need, Detailed Development Plans could also be prepared. ${ }^{25}$ As former chief architect István Schneller recalls, there were heated disputes in the 1990s about the decentralization of urban planning. He claims that even delegating zoning rights to districts was considered but ultimately abandoned. ${ }^{26}$ This competence ultimately stayed at the metropolitan level in the form of the General Regulatory Framework Plan. Districts could define further specifications in their Regulatory Plans, although these were supposed to be in conformity with the city's Framework Plan.

The change in the legal environment forced the city government to convert the GUP of 1997 into an SSP one year after its preparation. ${ }^{27}$ However, the massive privatization of housing well under way and the first wave of the alienation of large development areas to private developers converged in the dramatically reduced capacity of the plan to properly steer the city's urban development. Besides having been overtaken by actual development, the plan also was not in full compliance with the new Building Law and the accompanying Decree on the Requirements of Settlement Development

23 Act LXVIII/1997 (July 24).

24 Ibid., Article 2., Section 29, translated by the author.

25 Act III/1964 (December 2), Article 6, Section 1.

26 In an interview with the author, March 29, 2011.

27 Enacted with Council Decree 48/1998 (October 15). 
and Building, ${ }^{28}$ notwithstanding of the fact that its sheer existence was required by these. It used old terminologies and methods in distinguishing between zones where building was permitted and zones where it was not, and it failed to include all the supporting materials mandated by the new regulations. ${ }^{29}$ Furthermore, its main priorities had already been declared by other programs or plans beforehand, or had by then been already realized. Therefore, rather than opening new horizons, the plan was restricted to recognizing and legitimizing changes that had been already in the making. Its preamble disclosed the following goals for Budapest's urban development: 1) Extensive growth to be replaced by inner structural development; 2) Developments aiming to preserve the urban structure; 3) The renewal of urban areas; 4) Extending supply to meet private development demand; 5) Preserving land for infrastructure; 6) Upgrading public spaces; and 7) Heritage protection.

For the first goal, the initial wave of large private developments densifying Budapest's second urban belt was already well under way at the time when the 1998 SSP was adopted. The West End City Center, a shopping mall and office complex adjacent to the Western Railway Station, was under construction in 1998; while the Millennial City Center, a giant mixed-use development on land formerly designated for the $1996 \mathrm{EXPO},{ }^{30}$ was announced, and the development area was tendered. Objectives 2 and 7 - preserving the existing urban structure and protecting the built heritage shed light on the protectionist attitude of urban planning at the time. This was responsible for the lack of significant revisions of the city's structure, whereas drastic changes to ownership, mobility, and investment types would have demanded such reconsiderations. A hostile attitude towards iconic architecture and high-rise developments in the decades following the regime change are good examples of the era's conservatism, concurrently celebrated by many as a defense of the built environment against overwhelming market demand. While Prague built projects in its historic part of town by star architects Frank O. Gehry and Jean Nouvel soon after the regime change, ${ }^{31}$ and Warsaw erected a new central business district to reduce the dominance of the Stalinist Palace of Culture over the city's landscape (Fig. 9), all such attempts failed in Budapest during the 1990s and 2000s. Prominent among these were unrealized projects by Zaha Hadid (Fig. 10), Hani Rashid, and Norman Forster, invariably criticized for being alien to their local context and for the fact that their height rose above the rooftops of Budapest's eclectic downtown. However, not only proposals by internationally renowned architects remained unrealized. The general absence of projects of symbolic significance, celebrating the dawn of the new era, is conspicuous. The development of the first two decades following the regime change is characterized by the proliferation of private investor projects. The combination of post-industrial wasteland and structurally weak, deteriorated neighborhoods ${ }^{32}$, combined with the second belt's favorable position within the urban topology and the availability and affordability of land there, resulted in this trend being most prominent in the vicinity of Budapest's middle ring road, as the Corvin-Quarter, just one in a series of similar developments, illustrates (Fig. 11).

What is striking is that the 1998 SSP's modus operandi (Fig. 12) still remained largely unadjusted either to the changed circumstances of the economy and the real estate market, or to the emerging conflicts of interest between the national government, Budapest's agglomeration, the city, and its districts. Let me illustrate this with an example: if the development of an investor cluster including a shopping mall, offices, and apartments did not fit Budapest's Settlement Structure Plan, the concerned district designated the area as a neighborhood center and, thus, dragged it into the scope of its authority. It then ordered detailed planning which it outsourced, due to its insufficient resources

28 Government Decree 253/1997 (December 20).

29 Article 3 of the 1997 Decree on the Requirements of Settlement Development and Building requires a study on telecommunications - this was missing from the 1998 SSP. The plan was also not in conformity with the landuse categories introduced in the Article 6 of the Decree. The new Building Law's Article 11, Section 4 demands identifying factors affecting or potentially endangering the proposed land-use (such as mining, pollution, flooding, etc.). This requirement was not met by the 1998 SSP either.

30 Budapest was to host the world fair in 1996. The goverment withdrew the Hungarian bid for hosting the world fair in 1996 as part of an austerity package, made unavoidable by spiraling budgetary deficits.

31 The Dancing House (Czech: Tančící dům) by Vlado Milunić in cooperation with Frank O. Gehry and built between 1992 and 1996 and the Golden Angel (Czech: Zlatý Anděl), designed by Jean Nouvel. The project commenced in 1994 and was completed in November 2000.

32 The sociologist Iván Szelényi coined the term camelback urbanization for the slum formation between historic centers and peripheral new towns, characteristic of the socialist city [Szelényi, 1983]. 

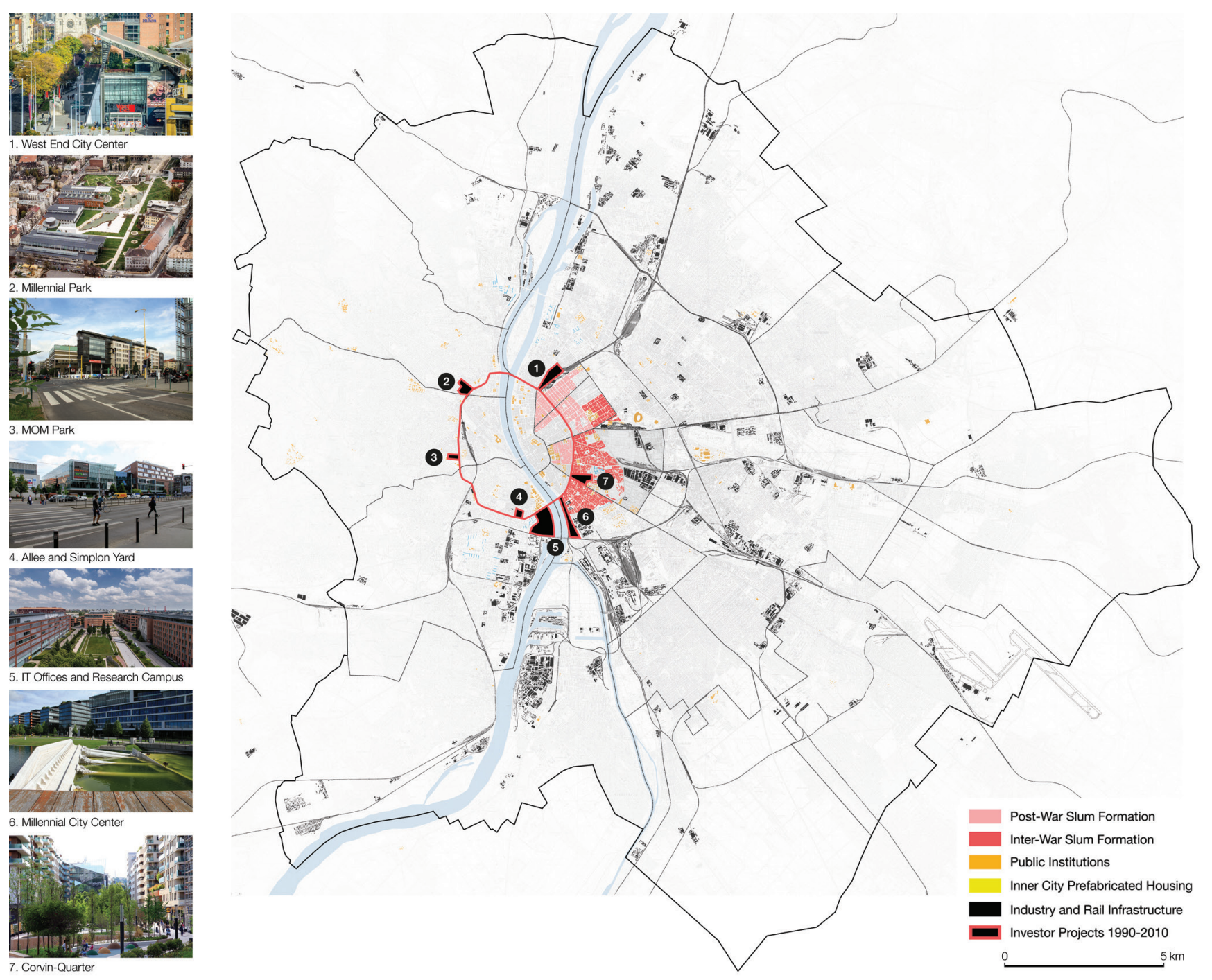

Fig. 11. Slum formation, industrial land, and private investor projects in Budapest's second urban belt

Source: Illustration by the author, 2013. Base map: segments L-34-14 and L-34-15, Hungarian State Topography Map 1:25000, 1987. Photo 1 by Sándor Csudai, MTI News Agency, 2016, photo 2 by CÉH Zrt., 2002, photos 3-7 by Ágnes Melles, 2018.

to the very firm that designed the project's architecture for the private developer - charging the development with conflicts of interest on multiple levels. ${ }^{33}$

The uncoordinated timing of amendments to different regulative instruments, and the resulting legal loopholes is the fifth apparent tension of Hungary's post-socialist planning.

\section{Belated Farewell to the Socialist Plan}

It was not until the mid-2000s, a decade and a half into the new political regime, that the planning apparatus' adjustment to the new political and economic circumstances finally took place, mostly catalyzed by Hungary's accession to the European Union in 2004. A new National Settlement Structure Plan was issued to coordinate the spatial planning of cities, an Agglomeration Development Act was enacted for regulating the relationship between the developments in Budapest and its metropolitan

33 The Allee shopping mall and ist surrounding areas were erected in 2009. The architecture firm developing the mall's designs was also commissioned by the municipality to prepare amendments to the District Regulation Plan - by way of a contract between the district and the private developer, ING Real Estate. 


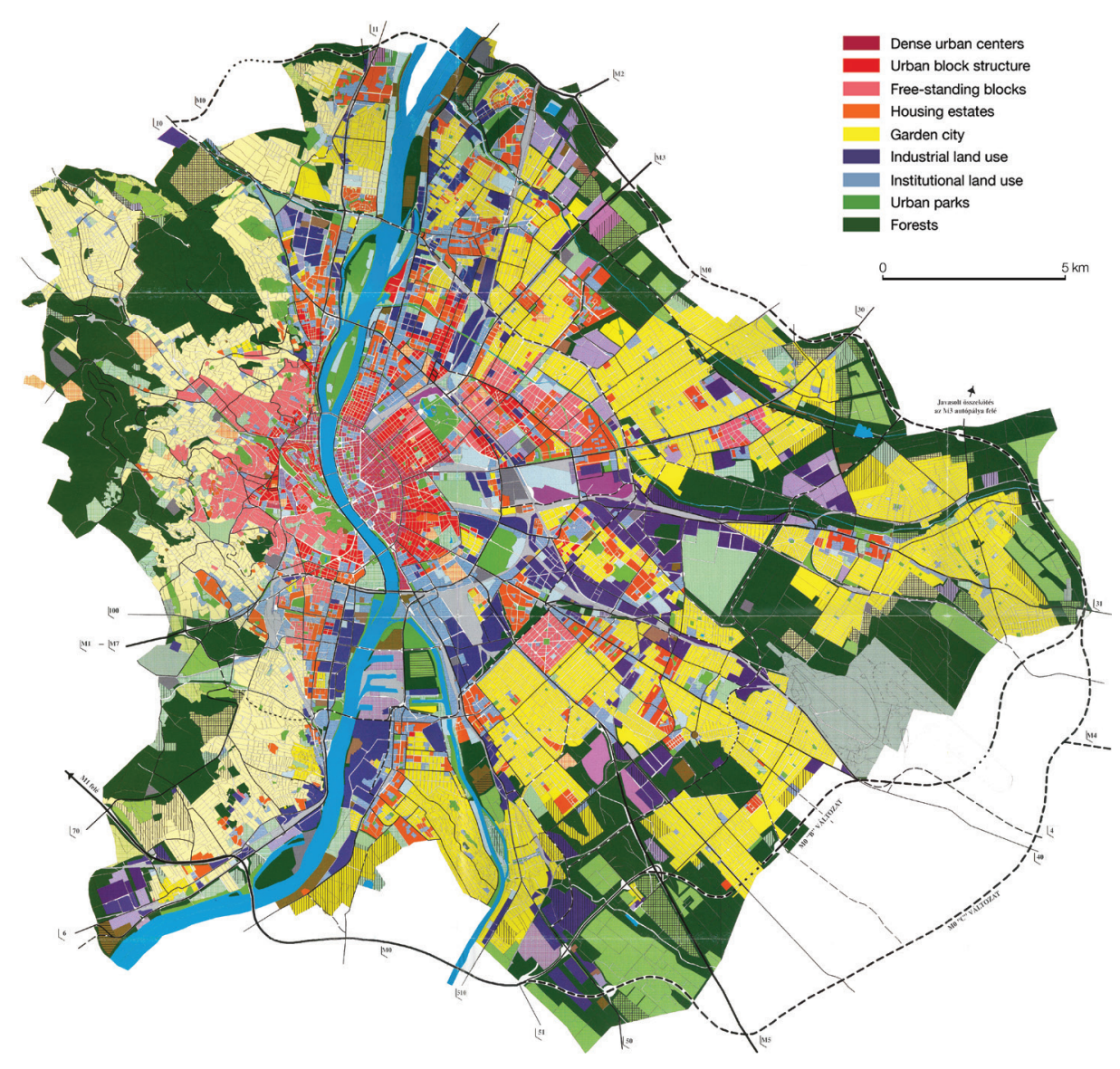

Fig. 12. The 1998 Settlement Structure Plan of Budapest

Source: Budapest Főváros Városépítési Tervező (BFVT) Kft., 2005.

region, and Budapest's new Settlement Structure Plan, and the first urban plan in accordance with the requirements of the 1997 Building Law has was adopted. ${ }^{34}$ Finally, the translation of the new SSP from 2005 (Fig. 13) into a medium-term Urban Development Program, the so-called Podmaniczky Program, came into effect. ${ }^{35}$

As another important novelty of the 2000s, Integrated Urban Development Strategies (IUDS) as complex long-term strategies made their appearance, required by the European Union as a precondition for settlements to become eligible for its urban renewal funds. By the time the first IUDS of Budapest was enacted by its City Council, ${ }^{36}$ most districts had already published their own strategies as it was not clear which administrative level would be eligible to apply for the EU-funds. To resolve this controversy, a document called 'the Frame of the Integrated Urban Development Strategies' was introduced and declared to be superior to the districts' strategies. Budapest's adopted IUDS was then based on this resolution. It introduced and prioritized six main development areas and made management and policy proposals for each of these, as well as for their synchronization with each other and with the districts' integrated strategies. ${ }^{37}$

34 Decree 1125/2005 (May 25) of Budapest's City Council.

35 Decree 1096/2006 (June 29) of Budapest's City Council.

The program was based on the 2003 Urban Development Concept and named after Frigyes Podmaniczky, vice-president of Budapest's Communal Work Council between 1873 and 1905, an important protagonist of Budapest's massive development towards the end of the 19th century.

36 Decree 2133/2008 (December 18) of Budapest's City Council.

37 'ITS Budapest Stratégia', accessed April 15, 2017 <budapest.hu/Documents/Integralt_Varosfejlesztesi_Strategia/ BP_ITS_Strategia_Megalapozo.pdf>. 


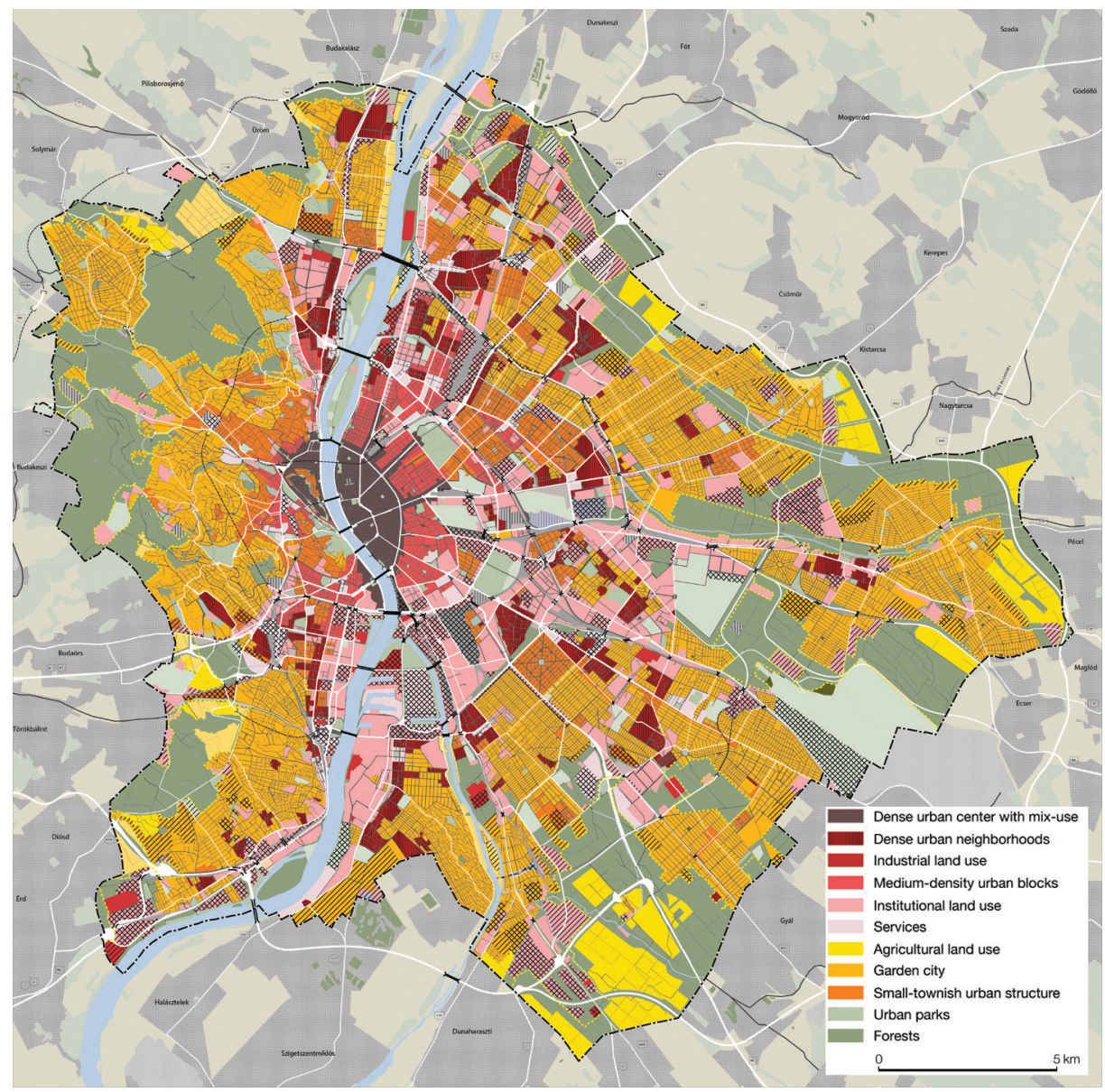

Fig. 13. The 2005 Settlement Structure Plan of Budapest

Source: Budapest Főváros Városépítési Tervező (BFVT) Kft., 2005.

Another year later, in an attempt to adjust the Hungarian settlement planning to the European Commission's directives, a Government Decree was issued on the norms and substantive criteria of settlement development strategies. ${ }^{38}$ Consequently, one can assert that by 2010 the spatial planning regime in Budapest became fully harmonized with EU norms and its current form took shape, putting an end to two long decades of transformation. Ironically, with a new government entering power the same year, a general trend at recentralizing authority emerged whereby the state also overruled local governments in matters related to urban planning - for example by using legislation to remove major urban development projects from the authority of Budapest's system of planning regulations. This provides a natural ending to the era under investigation.

As this paper demonstrated, the persistence of the socialist apparatus of urban planning resulted in major internal tensions within the planning regime. This dysfunctionality, in combination with the lack of clarity in the division of competence between the city and its uniquely powerful districts and the massive privatization of apartments to tenants, resulted in weak municipal governance and the inability of public authorities to provide a proper vision on how the city should develop. As a result, in the period under investigation, the city's political leaders were only partially able to keep structural changes under control, which contributed to the proliferation of business-dominated development projects not integrated into any grand urban design. 


\section{References}

ITS Budapest Stratégia. Available at: budapest.hu/Documents/Integralt_Varosfejlesztesi_Strategia/BP_ITS_Strategia_ Megalapozo.pdf (accessed 15 April 2017).

A Fövárosi Városrehabilitációs Keret müködésének kiértékelése [Evaluation of Budapest's Urban Renewal Fund] (2001). Budapest: Városkutatás Kft.

Andrusz G., Harloe M., Szelényi I. (eds). (1996) Cities After Socialism. Urban and Regional Change and Conflict in PostSocialist Societies. Oxford: Blackwell Publishers Inc.

Bertaud A., Renaud B. (1997) Socialist cities without land markets. Journal of Urban Economics, vol. 41, no 1, pp. 137151.

BFVT public interest report (2014). Available at: http://www.bfvt.hu/download.php?98bdd9a700fd3fdaeaead249522 f88dd (accessed 13 April 2017).

Blanchard O. (1999) An Interview with János Kornai. Macroeconomic Dynamics, vol. 3, no 3, pp. 427-450.

Dániel Z. (1996) A bérlakás-privatizáció paradoxona. Nemzeti ajándék vagy ráfizetés? [The paradox of privatizing rented housing: a national gift or a bad bargain?]. Közgazdasági Szemle (Economic Review-monthly of the Hungarian Academy of Sciences), vol. 43, no 3, pp. 204-230.

Demszky G. (2012) Elveszett szabadság: láthatatlan történeteim [Lost Freedom - My Invisible Stories]. Budapest: Noran Libro, p. 269.

Gábor C. et al. (2010) Város - tervező - társadalom [City, Planner, Society]. Budapest. Sík Kiadó, p. 483.

Hamilton F.E.I.,Andrews K.D., Pichler-Milanović N. (2005) Transformation of cities in Central and Eastern Europe towards globalization. Tokyo: United Nations University Press.

Jałowiecki B. (1988) Społeczne wytwarzanie przestrzeni [Social Production of Space]. Książka i Wiedza, p. 195.

Kiss D. (2018) Modeling Post-Socialist Urbanization. The Case of Budapest. Basel: Birkhäuser Verlag, pp. 58-65; 135179.

Kondor A.Cs., Szabó B. (2007) A lakáspolitika hatása Budapest városszerkezetére az 1960-as és az 1970-es években [Impact of the housing policy on spatial structure of Budapest in the 1960's and 1970's]. Földrajzi értesitó, vol. 56, no 3-4, pp. 237-269 (242).

Ladányi J. (2007) A lakóhelyi szegregáció változó formái Budapesten [Changing Forms of Residential Segregation in Budapest]. A történelmi városközpontok átalakulásának társadalmi hatásai [Societal Impacts of the Historical Centers' Transformation] (G. Enyedi (ed.)). Budapest: MTA Társadalomkutató Központ, pp. 199-215 (206).

Némedi-Varga S. (1998) A külföldi tőkeberuházások a világgazdaságban [Foreign Capital Investment in the World Economy]. Statisztikai Szemle, pp. 390-406 (391). Available at: www.ksh.hu/statszemle_archive/1998/1998_0405/F1998_04-05_390.pdf (accessed 18 April 2017).

Rainer J. (2010) Magyarország története. A Kádár-korszak 1956-1989. Budapest: Kossuth Kiadó, pp. 40-44.

Somogyi E., Szemző H., Tosics I. (2007) Városrehabilitáció kétszintű önkormányzati rendszerben: budapesti sikerek és problémák (1994-2006) [Urban Renewal in the Dual-Tier Municipal System: Successes and Issues in Budapest (1994-2006)]. A történelmi városközpontok átalakulásának társadalmi hatásai [Societal Impacts of the Historic Centers' Transformation] (G. Enyedi (ed.)). Budapest: MTA Társadalomkutató Központ, pp. 69-91 (77, 80).

Stanilov K. (2007) The post-socialist city: urban form and space transformations in Central and Eastern Europe after socialism. Dordrecht: Springer.

Stanilov K. (2007) Urban Planning and the Challenges of Post-Socialist Transformation. The post-socialist city: urban form and space transformations in Central and Eastern Europe after socialism (K. Stanilov (ed.)). Dordrecht: Springer, pp. 413-425 (414).

Szelényi I. (1983) Urban inequalities under state socialism. Oxford: Oxford University Press, p. 148.

Tosics I. (2013) A Conceptual Framework of the Post-Socialist Transition of Cities. Policy, planning, and people: promoting justice in urban development (N. Carmon, S.S. Fainstein (eds)). University of Pennsylvania Press, pp. 76-100.

Tsenkova S. (2011) Venturing into unknown territory: Strategic spatial planning in post-communist cities. Urbani izziv, vol. 2245, no 22, pp. 83-99 (85).

Tsenkova S., Nedovic-Budic Z. (2006) The Urban Mosaic of Post-Socialist Europe Space, Institutions and Policy. Heidelberg: Physica.

Verdery K. (1996) What Was Socialism, and What Comes Next? Princeton: Princeton University Press, p. 21. 


\section{НОВЫЕ НОРМЫ - СТАРЫЙ МОДУС. \\ НАПРЯЖЕННОСТЬ ОТ СОЦИАЛИСТИЧЕСКОГО ПЛАНИРОВАНИЯ, ПЕРЕЖИВШЕГО СМЕНУ РЕЖИМА В ВЕНГРИИ}

Дэниэл Кишш, PhD, доцент, преподаватель Института городского дизайна (Network City Landscape), ETH Zurich; HIL H 44.1, Stefano-Franscini-Platz 5, CH-8093 Zürich.

E-mail: kiss@arch.ethz.ch

Постсоциалистическая трансформация - широко распространенное явление с множественными вариациями. Даже если исследование относится к странам Восточной Европы, развитие каждой из них в отдельности тесно связано с локальным социоэкономическим и историческим контекстом.

То же самое относится к становлению систем планирования в этих странах, которое шло не по единой модели. Тем не менее общим был запрос на новые подходы к регулированию пространственного развития, ориентированные на рыночную экономику в противовес социалистической планировочной традиции, согласно которой план в большей степени - это горизонтальная структура, синтезирующая отраслевые государственные инвестиционные программы. Несмотря на то что дискурс о постсоциалистической урбанизации широко представлен в городской географии, экономике и управлении, работ по трансформации планировочных систем в этом контексте довольно мало.

Первые исследования в этой области предлагали обобщенное описание связей между земельными реформами, отчуждением прав собственности и развитием институтов планирования, не имея достаточного эмпирического материала для работы. В ответ на эти ограничения данная статья представляет собой глубокое эмпирическое исследование отдельных случаев трансформации системы городского планирования в Будапеште в период с 1990 по 2010 г. Тем самым исследование охватывает как время введения новых законодательных инициатив, так и период, когда можно проанализировать появившиеся противоречия и несвоевременность некоторых шагов. Экономические реформы 1960-х годов уже были нацелены на децентрализацию планирования и управления при социализме, а статичность системы пространственного планирования сохранялась даже после смены режима.

В период постсоциалистической децентрализации власти политические полномочия, касающиеся городского планирования, были переданы на более низкие уровни. Но система долгое время оставалась оторванной от экономического и политического контекста. Гипотеза состоит в следующем: существует связь между стойкостью системы социалистического планирования и постсоциалистическим подходом по принципу невмешательства (laissez-faire) в городское развитие, что привело к большому количеству противоречий между планированием и экономикой и невозможности функционирования старой системы в новых рыночных условиях.

Методология данного исследования основана на содержательном анализе политических документов и вторичных источниках аналитической информации, относящихся к системе городского планирования в Будапеште в исследуемый период, и дополнена интервью с основными заинтересованными сторонами.

Ключевые слова: постсоциалистический; система планирования; девелопмент; Будапешт; приватизация; градостроительная документация

Цитирование: Kiss D. (2018) New Norms - Old Modus. Tensions from Socialist Planning Surviving the Regime Change in Hungary // Городские исследования и практики. Т. 3. № 4. С. 18-34.

DOI: https://doi.org/10.17323/usp34201818-34 


\section{Источники}

A Fővárosi Városrehabilitációs Keret működésének kiértékelése [Evaluation of Budapest’s Urban Renewal Fund] (2001). Budapest: Városkutatás Kft.

Andrusz G., Harloe M., Szelényi I. (eds) (1996) Cities After Socialism. Urban and Regional Change and Conflict in PostSocialist Societies. Oxford: Blackwell Publishers Inc.

Bertaud A., Renaud B. (1997) Socialist cities without land markets // Journal of Urban Economics. Vol. 41. No. 1. P. 137-151.

BFVT public interest report (2014). Режим доступа: http://www.bfvt.hu/download.php?98bdd9a700fd3fdaeaead24 9522f88dd (дата обращения: 13.04.2017).

Blanchard O. (1999) An Interview with János Kornai // Macroeconomic Dynamics. Vol. 3. No. 3. P. 427-450.

Dániel Z. (1996) A bérlakás-privatizáció paradoxona. Nemzeti ajándék vagy ráfizetés? [The paradox of privatizing rented housing: a national gift or a bad bargain?] // Közgazdasági Szemle (Economic Review-monthly of the Hungarian Academy of Sciences). Vol. 43. No. 3. P. 204-230.

Demszky G. (2012) Elveszett szabadság: láthatatlan történeteim [Lost Freedom - My Invisible Stories]. Budapest: Noran Libro. P. 269.

Gábor C. et al. (2010) Város - tervező - társadalom [City, Planner, Society]. Budapest. Sík Kiadó. P. 483.

Hamilton F.E.I., Andrews K.D., Pichler-Milanović N. (2005) Transformation of cities in Central and Eastern Europe towards globalization. Tokyo: United Nations University Press.

ITS Budapest Stratégia. Режим доступа: budapest.hu/Documents/Integralt_Varosfejlesztesi_Strategia/BP_ITS_ Strategia_Megalapozo.pdf (дата обращения: 15.04.2017).

Jałowiecki B. (1988) Społeczne wytwarzanie przestrzeni [Social Production of Space]. Książka i Wiedza. P. 195.

Kiss D. (2018) Modeling Post-Socialist Urbanization. The Case of Budapest. Basel: Birkhäuser Verlag. P. 58-65; 135179.

Kondor A.Cs., Szabó B. (2007) A lakáspolitika hatása Budapest városszerkezetére az 1960-as és az 1970-es években [Impact oft he housing policy on spatial structure of Budapest in the 1960's and 1970's // Földrajzi értesítő. Vol. 56. No. 3-4. P. 237-269 (242).

Ladányi J. (2007) A lakóhelyi szegregáció változó formái Budapesten [Changing Forms of Residential Segregation in Budapest] // A történelmi városközpontok átalakulásának társadalmi hatásai [Societal Impacts of the Historical Centers'Transformation] / G. Enyedi (ed.). Budapest: MTA Társadalomkutató Központ. P. 199-215 (206).

Némedi-Varga S. (1998) A külföldi tőkeberuházások a világgazdaságban [Foreign Capital Investment in the World Economy] // Statisztikai Szemle, P. 390-406 (391). Режим доступа: www.ksh.hu/statszemle_ archive/1998/1998_04-05/F1998_04-05_390.pdf (дата обращения: 18.04.2017).

Rainer J. (2010) Magyarország története. A Kádár-korszak 1956-1989. Budapest: Kossuth Kiadó. P. 40-44.

Somogyi E., Szemző H., Tosics I. (2007) Városrehabilitáció kétszintű önkormányzati rendszerben: budapesti sikerek és problémák (1994-2006) [Urban Renewal in the Dual-Tier Municipal System: Successes and Issues in Budapest (1994-2006)] // A történelmi városközpontok átalakulásának társadalmi hatásai [Societal Impacts of the Historic Centers' Transformation] / G. Enyedi (ed.). Budapest: MTA Társadalomkutató Központ. P. 69-91 (77, 80).

Stanilov K. (2007) The Post-Socialist City: Urban Form and Space Transformations in Central and Eastern Europe after Socialism. Dordrecht: Springer.

Stanilov K. (2007) Urban Planning and the Challenges of Post-Socialist Transformation // The post-socialist city: urban form and space transformations in Central and Eastern Europe after socialism / K. Stanilov (ed.). Dordrecht: Springer. P. 413-425 (414).

Szelényi I. (1983) Urban Inequalities under State Socialism. Oxford: Oxford University Press. P. 148.

Tosics I. (2013) A Conceptual Framework of the Post-Socialist Transition of Cities. Policy, Planning, and People: promoting justice in urban development / N. Carmon, S.S. Fainstein (eds). University of Pennsylvania Press. P. $76-100$.

Tsenkova S. (2011) Venturing into Unknown Territory: Strategic Spatial Planning in Post-Communist cities // Urbani izziv. Vol. 2245. No. 22. P. $83-99$ (85).

Tsenkova S., Nedovic-Budic Z. (2006) The Urban Mosaic of Post-Socialist Europe Space, Institutions and Policy. Heidelberg: Physica.

Verdery K. (1996) What Was Socialism, and What Comes Next? Princeton: Princeton University Press. P. 21. 